\title{
First evidence of high-molecular-weight bacteriocin (tailocin) produced by Antarctic Pseudomonas spp.
}

\author{
Kateřina Snopková ${ }^{1}$, Ivo Sedláček ${ }^{2}$, David Šmajs ${ }^{1 *}$ \\ ${ }^{1}$ Department of Biology, Faculty of Medicine, Masaryk University, Kamenice 5, 62500 \\ Brno, Czech Republic \\ ${ }^{2}$ Czech Collection of Microorganisms, Department of Experimental Biology, Faculty of \\ Science, Masaryk University, Kamenice 5, 62500 Brno, Czech Republic
}

\begin{abstract}
Cold-adapted soil ecosystems represent dynamic communities varying in a structure, microbial abundance and metabolic activity. To antagonize competitors, soil bacteria produce a variety of inhibitory agents. We tested production of antimicrobials in Pseudomonas spp. isolated in James Ross Island, Antarctica, and performed transmission electron microscopic analyses of selected high-molecular-weight bacteriocin particles. The dimensions of R-tailocins produced by Pseudomonas sp. P2422 were $168 \pm 2.0 \mathrm{~nm}$ (length) and $16 \pm 0.8 \mathrm{~nm}$ (width) thus representing one of the largest tailocins secreted by Pseudomonas spp. To our knowledge, this is the first evidence of tailocin production by bacteria originated from polar regions.
\end{abstract}

Key words: pyocin, tailocin, phage tail-like particle, antimicrobial agents, James Ross Island

DOI: $10.5817 / \mathrm{CPR} 2018-2-14$

\section{Introduction}

Bacteria in microbial communities sharing similar niches frequently encode antimicrobial agents that are able to antagonize competitors (Riley et Gordon 1999, Sánchez et al. 2009). Bacteriocins are antibacterial proteins produced by bacteria selectively kill closely related bacterial species (Cascales et al. 2007). These agents were identified in all major lineages of bacteria (Riley et Wertz 2002, Tagg et al.
1976) and some archaea (e.g. particular Halobacterium and Sulfolobus strains; O'Connor et Shand 2002). Although ecological aspects of bacteriocin production in the nature are not fully elucidated, bacteriocins play an important role in intra- and inter-species bacterial interactions. Study performed by Kerr et al. (2002) demonstrated that balance among producers, susceptible and resistant strains was maintain-

Received September 6, 2018, accepted November 13, 2018.

*Corresponding author: D. Šmajs $<$ dsmajs@med.muni.cz>

Acknowledgements: The authors thank to the scientific infrastructure of the J. G. Mendel Czech Antarctic Station (supported by the MEYS CR, Project LM2015078 CzechPolar2). This work was supported by the Grant Agency of the Czech Republic (GA16-21649S) to DS. Transmission electron microscopy was performed at the Department of Histology and Embryology, Faculty of Medicine, Masaryk University with assistance of Ladislav Ilkovics and Dobromila Klemová. 
ed in static laboratory communities. Due to narrow target spectra, the bacteriocins could represent the next generation of antimicrobial agents selectively inhibiting particular bacterial species. Bacteriocins produced by Antarctic bacteria remain almost unstudied although we could profit from their extraordinary properties including their activity at low temperature.

The high-molecular-weight (HMW) bacteriocins are referred as tailocins (Ghequire et De Mot 2014, Rybakova et al. 2013). Microscopically, tailocins resemble phage tails and also a common ancestor of tailocins and phages has been proposed (Nakayama et al. 2000). Two morphologically distinct types of tailocins could be distinguished (Ghequire et De Mot 2015, Michel-Briand et Baysse 2002): the R-type tailocins are rigid and contractile particles whereas the F-type tailocins represent flexible, noncontractile structures. A typical morphology of R-type particle is depicted in Fig. 1. Tailocin production is upregulat-

\section{Material and Methods}

\section{Bacterial strains}

All 36 strains used within the study were obtained from the Czech Collection of Microorganisms, Brno, Czech Republic. Strains were collected at the James Ross Island, Antarctica, in the neighborhood of the Johann Gregor Mendel Station $(\varphi=$ $63^{\circ} 48^{\prime} 02^{\prime \prime} \mathrm{S}, \lambda=57^{\circ} 52^{\prime} 57^{\prime \prime} \mathrm{W}$ ) during the

\section{Screening for tailocin activity}

A double layer plate assay was used for bacteriocin screening (Micenková et al. 2014). The set of Antarctic Pseudomonas spp. was tested in all-by-all assay, i.e. each strain was used as a potential producer and an indicator. Briefly, a producer strain was inoculated on TY agar $\left(8 \mathrm{~g} \cdot \mathrm{l}^{-1}\right.$ casein, $5 \mathrm{~g} \cdot \mathrm{l}^{-1}$ yeast extract, $5 \mathrm{gl}^{-1}$ sodium chloride, $\mathrm{pH}$ ed in the stress conditions, e.g., under high UV radiation or starvation (Michel-Briand et Baysse 2002). Binding of the particles to the susceptible cells leads to depolarization of the cytoplasmic membrane and cell death (Dyke et Berk 1974, Smit et al. 1969). Tailocins seem to be promising agents in elimination of human pathogens, e.g., Shiga toxin-producing Escherichia coli (Scholl et al. 2009) or Clostridium difficile (Gebhart et al. 2015), as well as plant pathogens (Príncipe et al. 2018).

The aim of the present study was the identification of antibacterial agents produced by Pseudomonas spp. isolated in the North-east Antarctic Peninsula region (according to classification by Terauds et Lee 2016) and microscopic characterization of selected tailocin types. The particles were visualized using dark-field transmission electron microscopy and their dimensions were compared to previously described tailocins produced by mesophilic pseudomonads.

Czech scientific expeditions in 20072009. Pseudomonas sp. P2422 was isolated from stony soils and identified to the genera level using standard biochemical tests and $r r n$ and rpoD sequence analyses (data not shown).

7.5) supplemented with mitomycin $\mathrm{C}$ (final concentration $0.5 \mu \mathrm{gml}^{-1}$ ) and cultivated at $4^{\circ} \mathrm{C}$ for 7 days. Subsequently, a producer was killed by chloroform vapors and overlayed with soft TY medium containing $10^{8}$ cells of indicator culture. Then, the cultivation continued at $25^{\circ} \mathrm{C}$ for $24 \mathrm{~h}$. Around producer macrocolonies, typical 
narrow inhibition zones (around 1-2 mm wide) were formed. Particle character of produced inhibitor agents was confirmed by the insensitivity to protease digestion (trypsin at the concentration of $0.5 \mu \mathrm{gml}^{-1}$ and proteinase $\mathrm{K}$ at the concentration of $0.1 \mathrm{mg} \mathrm{ml}^{-1}$ ) according to the modified double layer plate assay (Bakkal et al. 2010). All tests were repeated twice in independent replicates.

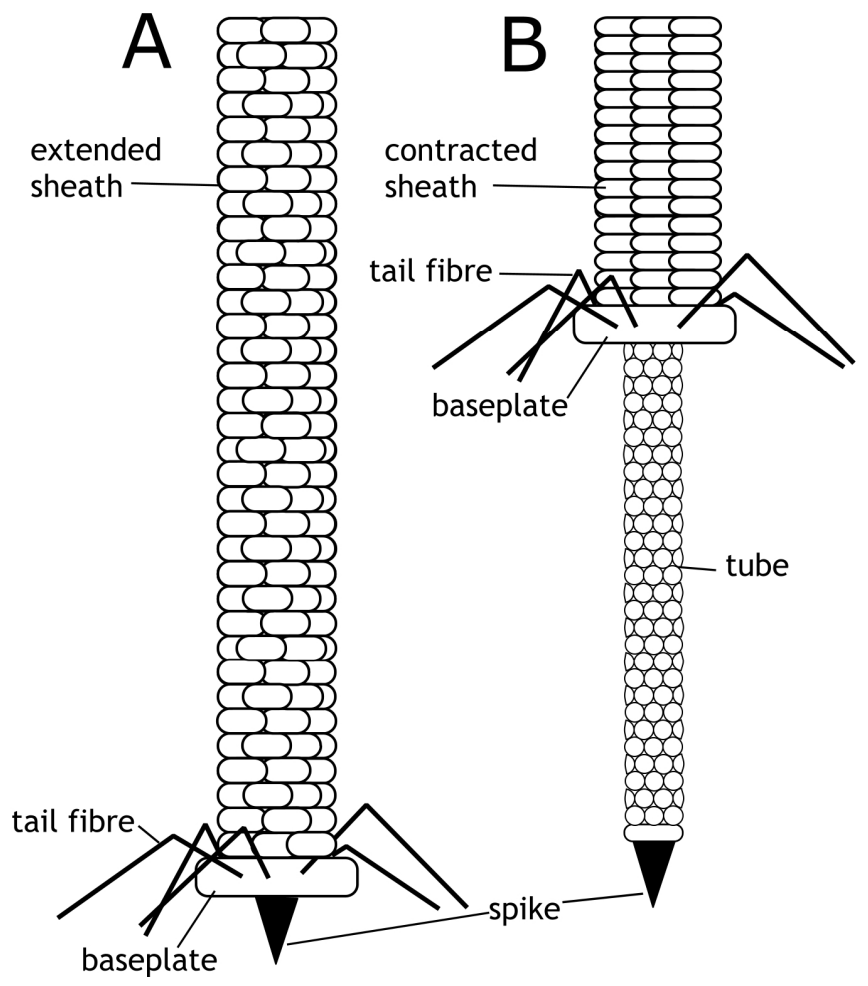

Fig. 1. A schematic visualization of R-type tailocin; relaxed particle (A), contracted particle (B). The particle consists of a rigid tube, contractible sheath, tail fibres (responsible for attachment to the target cell), baseplate and spike. According to Ghequire et De Mot (2015), modified.

\section{Dark-field transmission electron microscopy}

Pseudomomas sp. P2422 was used for further characterization using the transmission electron microscopy. The strain was cultivated in TY broth $\left(8 \mathrm{~g}^{-1} \mathrm{l}^{-1}\right.$ casein, $5 \mathrm{~g} \cdot \mathrm{l}^{-1}$ yeast extract, $5 \mathrm{~g} \cdot \mathrm{l}^{-1}$ sodium chloride, $\mathrm{pH}$ 7.5; HiMedia, Mumbai, India) at $25^{\circ} \mathrm{C}$ with shaking $(200 \mathrm{rpm})$ until the cell density reached 0.5 . Subsequently, mitomycin $\mathrm{C}$ was added $\left(0.5 \mu \mathrm{gml}^{-1}\right)$ and cultivation continued for following $3 \mathrm{~h}$. The tailocins secreted into the medium were purified according to Sambrook et Russell (2001) using 10\% PEG 8000 (Fisher Scientific, Waltham, United States) for the particle pelleting and resuspended in SM buffer $\left(100 \mathrm{mM} \quad \mathrm{NaCl}, \quad 8 \mathrm{mM} \quad \mathrm{MgSO}_{4} \cdot 7 \mathrm{H}_{2} \mathrm{O}\right.$, 50 mM Tris-Cl; HiMedia, Mumbai, India and Sigma-Aldrich, St. Louis, United States). The solution was applied to a $\mathrm{CsCl}$ gradient, centrifuged $\left(87,000 \mathrm{~g}, 10^{\circ} \mathrm{C}, 2 \mathrm{~h}\right)$, 
and the tailocin fraction was dialyzed against SM buffer overnight. For the transmission electron microscopy, $5 \mu \mathrm{l}$ was applied onto glow discharge-activated carboncoated grids (Pyser-SGI, Edenbridge,

\section{Micrograph analysis}

Software ImageJ (Schneider et al. 2012) was used for the transmission electron microscopy image processing. The longitu-
United Kingdom). Samples were stained with $2 \%$ (wt/vol) ammonium molybdate for $10-30 \mathrm{~s}$, and the tailocins were visualized with a MORGAGNI 268D microscope (FEI, Hillsboro, OR, USA).

\section{Results and Discussion}

dinal and transverse dimensions of the detected tailocins were measured in five independent images.

\section{Bacteriocin activity of Antarctic Pseudomonas strains}

During bacteriocin screening of 36 strains, sixteen of them (44.4\%) produced narrow inhibition zones resistant to protease digestion suggesting the secretion of high-molecular-mass tailocins. All the producers were non-susceptible to their own inhibition agent. The particles produced by the P2422 strain of Pseudomomas sp. affecting 5 of tested Antarctic Pseudomonas strains $(13.9 \%)$ were used for further characterization using the transmission elec- tron microscopy. Production of tailocin particles exhibiting some activity against other Antarctic strains probably contributes to the competitive fitness of the producer in the native bacterial community. The role of tailocin production as important competitive determinant in bacterial interactions has been proposed in several previous studies (Fischer et al. 2012, Ghequire et De Mot 2014, Mavrodi et al. 2009).

\section{Morphology of tailocin particles}

The dark-field transmission electron microscopy was used for visualization of the particles produced by strain P2422. Microscopy revealed particles resembling tails of T-even bacteriophages (Fig. 2). The sample contained double hollow cylindrical particles with an inner core encompassed by a contractile outer sheath which is a typical structure for the R-type pyocins. Several conformation states could be distinguish in the micrographs; (i) relaxed full-length particles with a visible sheath only, (ii) full-length tubes protruding from the contracted sheath, and (iii) empty contracted sheath. Further morphological char-

acteristics could be recognized such as e.g., perpendicular basal plates or spiral coiling of the contractile protein forming the sheath. The dimensions of the particles were measured in a detail. The length of extended R-tailocin produced by Pseudomonas sp. P2422 was $168 \pm 2.0 \mathrm{~nm}$, the width reached $16 \pm 0.8 \mathrm{~nm}$. Such dimensions represent one of the largest tailocins secreted by Pseudomonas spp. (see Table 1). Particles with very similar length has been previously isolated from plantassociated strain Pseudomonas putida BW11M1 (Ghequire et al. 2015). 

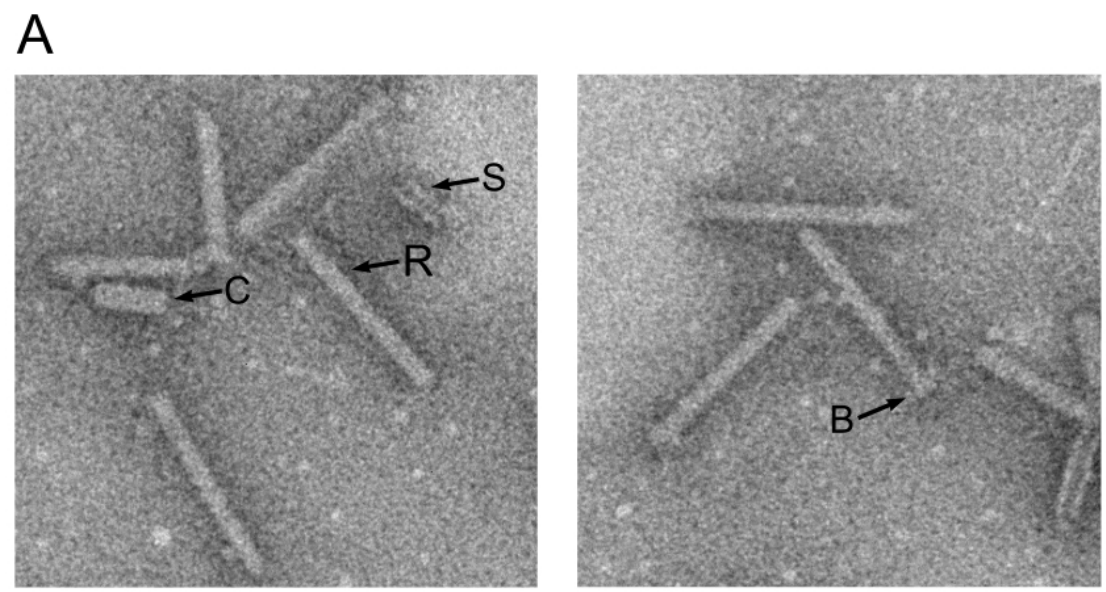

B

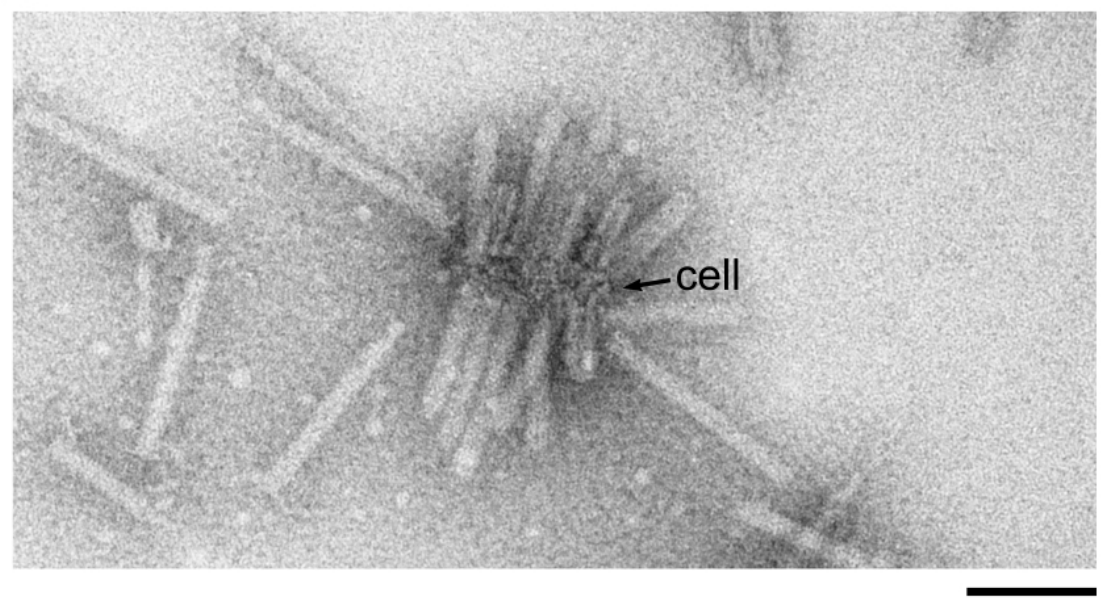

Fig. 2. Transmission electron micrographs of purified R-type tailocins produced by Pseudomonas sp. P2422 (A), cell under lysis surrounded by tailocins (B). Samples were negatively stained with $2 \%(\mathrm{wt} / \mathrm{vol})$ ammonium molybdate. $\mathrm{R}$, relaxed particle; $\mathrm{C}$, contracted particle; S, empty contracted sheath; B, baseplate. Scale bar represents $100 \mathrm{~nm}$.

On the other hand, R-pyocins produced by growth-promoting bacterium Pseudomonas fluorescens SF4c (Fernandez et al. 2017), rhizosphere-colonizing strain Pseudomonas chlororaphis 30-84 (which produce two R-tailocins differing in the length and in killing spectra; Dorosky et al. 2017, Dorosky et al. 2018) or nosocomial human pathogen Pseudomonas aeruginosa PA01 (Ito et Kageyama 1970) were found to be shorter. All the above-mentioned tail- ocins, however, are produced by mesophilic strains. Thus, no comparison with tailocin produced by cold-adapted species is available. The length of particles was shown to depend on a gene encoding a tape measure protein (Rybakova et al. 2015). The length of the gene is proportional to the length of the particle. On the other hand, no relationship between the particle length and other characteristics (e.g. effectivity or host killing spectra) has been identified so far. 
K. SNOPKOVÁ et al.

\begin{tabular}{llll}
\hline Producer strain & Length [nm] & Width [nm] & Reference \\
\hline \hline Pseudomonas sp. P2422 & $168 \pm 2.0$ & $16 \pm 0.8$ & this study \\
P. aeruginosa PA01 & 130 & 15 & Ito et Kageyama 1970 \\
P. putida BW11M1 & 167 & 13 & Ghequire et al. 2015 \\
P. chlororaphis 30-84 R-tailocin 1 & $118 \pm 0.62$ & - & Dorosky et al. 2017 \\
P. chlororaphis 30-84 R-tailocin 2 & $149 \pm 0.19$ & - & Dorosky et al. 2017 \\
P. fluorescens SF4c & $127 \pm 8$ & $16 \pm 2$ & Fernandez et al. 2017
\end{tabular}

Table 1. Dimensions of tailocins produced by selected Pseudomonas spp.

\section{Conclusion}

Pseudomonas spp. are one of the few bacteria capable to survive and profit in harsh Antarctic condition. Although production of HMW bacteriocins by Pseudomonas spp. is well known, no reports exist on cold-adapted pseudomonads. Our study demonstrates for the first time the ability of Antarctic Pseudomonas spp. to produce tailocins that likely provide an important ecological advantage in inter-strain competition. Due to a relatively high stability, these tailocins are good candidates for the further research focused on commercial applications.

\section{References}

Bakkal, S., Robinson, S. M., Ordonez, C. L., Waltz, D. A. and Riley, M. A. (2010): Role of bacteriocins in mediating interactions of bacterial isolates taken from cystic fibrosis patients. Microbiology, 156: 2058-2067.

Cascales, E., Buchanan, S. K., Duché, D., Kleanthous, C., Lloubès, R., Postle, K., Riley, M., Slatin, S. and CAVARD, D. (2007): Colicin biology. Microbiology and Molecular Biology Reviews, 71: 158-229.

Dorosky, R .J., Yu, J. M., Pierson, L. S. and Pierson, E. A. (2017): Pseudomonas chlororaphis produces two distinct R-tailocins that contribute to bacterial competition in biofilms and on roots. Applied and Environmental Microbiology, 83, 15.

Dorosky, R. J., Pierson, L. S. and Pierson, E. A. (2018): Pseudomonas chlororaphis produces multiple R-tailocin particles that broaden the killing spectrum and contribute to persistence in rhizosphere communities. Applied and Environmental Microbiology (Epub ahead of print).

DYKe, J., BERK, R. S. (1974): Growth inhibition and pyocin receptor properties of endotoxin from Pseudomonas aeruginosa. Proceedings of the Society for Experimental Biology and Medicine, 145: 1405-1408.

Fernandez, M., Godino, A., Príncipe, A., Morales, G. M. and Fischer, S. (2017): Effect of a Pseudomonas fluorescens tailocin against phytopathogenic Xanthomonas observed by atomic force microscopy. Journal of Biotechnology, 256: 13-20.

Fischer, S., Godino, A., Quesada, J. M., Cordero, P., Jofré, E., Mori, G. and Espinosa-Urgel, M. (2012): Characterization of a phage-like pyocin from the plant growth-promoting rhizobacterium Pseudomonas fluorescens SF4c. Microbiology, 158: 1493-1503.

Gebhart, D., LoK, S., Clare, S., Tomas, M., Stares, M., Scholl, D., Donskey, C. J., Lawley, T. D. and Govoni, G. R. (2015): A modified R-type bacteriocin specifically targeting 
Clostridium difficile prevents colonization of mice without affecting gut microbiota diversity. MBio. 6, 2.

GHEQUiRe, M.G.K., De Mot, R. (2014): Ribosomally encoded antibacterial proteins and peptides from Pseudomonas. FEMS Microbiology Reviews, 38: 523-568.

GHEQuiRe, M.G.K., De Mot, R. (2015): The tailocin tale: peeling off phage tails. Trends in Microbiology, 23: 587-590.

Ghequire, M. G. K., Dillen, Y., Lambrichts, I., Proost, P., Wattiez, R. and De Mot, R. (2015): Different ancestries of R tailocins in rhizospheric Pseudomonas isolates. Genome Biology and Evolution, 7: 2810-2828.

Ito, S., Kageyama, M. (1970): Relationship between pyocins and a bacterciophage in Pseudomonas aeruginosa. The Journal of General and Applied Microbiology, 16: 231-240.

Kerr, B., Riley, M. A., Feldman, M. W. and Bohannan, B. J. M. (2002): Local dispersal promotes biodiversity in a real-life game of rock-paper-scissors. Nature, 418: 171-174.

Mavrodi, D. V., Loper, J. E., Paulsen, I. T. and Thomashow, L. S. (2009): Mobile genetic elements in the genome of the beneficial rhizobacterium Pseudomonas fluorescens Pf-5. BMC Microbiology, 9, 8 .

Micenková, L., Štaudová, B., Bosák, J., Mikalová, L., LitTnerová, S., Vrba, M., Ševčíková, A., WozNICOVÁ, V. and ŠMAJS, D. (2014): Bacteriocin-encoding genes and ExPEC virulence determinants are associated in human fecal Escherichia coli strains. BMC Microbiology, 14, 109.

Michel-Briand, Y., BAysse, C. (2002): The pyocins of Pseudomonas aeruginosa. Biochimie, 84: 499-510.

Nakayama, K., Takashima, K., Ishihara, H., Shinomiya, T., Kageyama, M., Kanaya, S., Ohnishi, M., Murata, T., Mori, H. and Hayashi, T. (2000): The R-type pyocin of Pseudomonas aeruginosa is related to P2 phage, and the F-type is related to lambda phage. Molecular Microbiology, 38: 213-231.

O'CONNOR, E. M., SHAND, R. F. (2002): Halocins and sulfolobicins: the emerging story of archaeal protein and peptide antibiotics. Journal of Industrial Microbiology and Biotechnology, 28: 2331.

Príncipe, A., Fernandez, M., Torasso, M., Godino, A. and Fischer, S. (2018): Effectiveness of tailocins produced by Pseudomonas fluorescens SF4c in controlling the bacterial-spot disease in tomatoes caused by Xanthomonas vesicatoria. Microbiological Research, 212-213: 94-102.

RiLEY, M. A., GORDON, D. M. (1999): The ecological role of bacteriocins in bacterial competition. Trends in Microbiology, 7: 129-133.

RILEY, M. A., WERTZ, J. E. (2002): Bacteriocin diversity: ecological and evolutionary perspectives. Biochimie, 84: 357-364.

Rybakova, D., Radjainia, M., Turner, A., Sen, A., Mitra, A. K. and Hurst, M. R. H. (2013): Role of antifeeding prophage (Afp) protein Afp16 in terminating the length of the Afp tailocin and stabilizing its sheath. Molecular Microbiology, 89: 702-714.

Rybakova, D., Schramm, P., Mitra, A. K. and Hurst, M. R. H. (2015): Afp14 is involved in regulating the length of Anti-feeding prophage (Afp). Molecular Microbiology, 96: 815-826.

SAMBrooK, J., Russell, D.W. [eds] (2001): Molecular Cloning: A Laboratory Manual. vol.1, 3rd ed. Cold Spring Harbor Laboratory Press, New York, United States, 2100 p.

SÁnchez, L. A., Gómez, F. F. and Delgado, O. D. (2009): Cold-adapted microorganisms as a source of new antimicrobials. Extremophiles, 13: 111-120.

SChNeIDER, C. A., RASBAND, W. S. and Eliceiri, K. W. (2012): NIH Image to ImageJ: 25 years of image analysis. Nature Methods, 9: 671-675.

Scholl, D., Cooley, M., Williams, S.R., Gebhart, D., Martin, D., Bates, A. and Mandrell, R. (2009): An engineered R-type pyocin is a highly specific and sensitive bactericidal agent for the food-borne pathogen Escherichia coli O157:H7. Antimicrobial Agents and Chemotherapy, 53: 3074-3080.

Smit, J.A., Hugo, N. and DE KLerk, H.C. (1969): A receptor for a Proteus vulgaris bacteriocin. The Journal of General Virology, 5: 33-37. 
K. SNOPKOVÁ et al.

TAgG, J. R., Dajani, A. S. and Wannamaker, L. W. (1976): Bacteriocins of gram-positive bacteria. Bacteriological Reviews, 40: 722-756.

Terauds, A., LeE, J. R. (2016): Antarctic biogeography revisited: updating the Antarctic Conservation Biogeographic Regions. Diversity and Distributions, 22: 836-840. 